\title{
Seedling root-dip in phosphorus and biofertilizer added soil slurry method of nutrient management for transplanted rice in acid soil
}

\author{
Sagolshem Kalidas-Singh, Dwipendra Thakuria*
}

School of Natural Resource Management, College of Post Graduate Studies, Central Agricultural University (Imphal), Umiam - 793103, Meghalaya, India.

*Corresponding author: dwipendra.thakuria@gov.in thakuria.dwipendra@yahoo.co.in

\begin{abstract}
Management of phosphorus (P) in acid soils is becoming more challenging in the anticipated scenario of potential phosphate crisis in agriculture, because the P-use and -recovery efficiencies (PUE and PRE) of existing $\mathrm{P}$ management methods are notoriously low in acid soils. This investigation reported a rhizosphere-based $\mathrm{P}$ management method for improving P nutrition of rice (Oryza sativa L.) seedlings at the time of transplantation in order to support better root growth on post transplantation. By performing two independent incubation experiments, the critical doses of orthophosphate and incubation duration for seedling root-dip (SRD) in single super phosphate (SSP) amended soil slurry (a sandy clay loam Inceptisol, $\mathrm{pH} 4.3$ ) were found to be $112.5 \mathrm{mg}$ $\mathrm{P} \mathrm{kg}^{-1}$ soil and $10 \mathrm{~h}$, respectively using the critical curve approach. In field experiments, the rhizosphere-based $\mathrm{P}$ method (SRD in soil slurry + phosphate solubilizing bacteria, PSB + rock phosphate, RP $\left(30 \mathrm{~kg} \mathrm{P}_{2} \mathrm{O}_{5}\right.$ ha $\left.^{-1}\right)$ performed better than SSP broadcast as basal application $\left(60 \mathrm{~kg} \mathrm{P}_{2} \mathrm{O}_{5} \mathrm{ha}^{-1}\right)$ in terms of more root volume and $\mathrm{P}$ uptake of shoot and root at 45 days after transplantation (DAT), higher P uptake and content in rice grain and straw, enhanced PUE and PRE, comparable grain yield and 50\% reduction in P fertilizer input quantity. This rhizosphere based P management (SRD in soil slurry+PSB+RP) method may be vigorously exploited for managing $P$ nutrition in transplanted rice grown in acid soils.
\end{abstract}

Keywords: P use efficiency, P recovery efficiency, Phosphate solubilising bacteria, Rhizosphere-based P management, Rock phosphate, SSP broadcast. 


\section{Introduction}

The limited availability of phosphorus (P) for rice plant growth in highly weathered acid soils of tropics and sub-tropics is an emerging threat to the food security of the half of the world's population (FAOSTAT, 2016). Rice production is mainly constrained by low P-use efficiency (PUE) and P-recovery efficiency (PRE) in acid soils (Fageria et al., 2015), because $\mathrm{P}$ added to acid soils is fixed (50 to $90 \%$ of applied phosphatic fertilizer) as insoluble phosphates of $\mathrm{Al}^{+3}$ and $\mathrm{Fe}^{+2}$ (Bhattacharyya et al., 2015; Redel et al., 2016). Though the application of phosphatic fertilizers had dramatically increased yields of rice from an acreage of $30-40 \%$ of world's arable land (Bijay-Singh and Singh, 2017) those belong to Inceptisols, Oxisols, Alfisols, and Ultisols concentrated in Brazil, Columbia, Venezuela, Central Africa, and Southeast Asia, but low PUE $(<20$ to $25 \%)$ and PRE (approximate 10\%) has been reported (von Uexküll and Mutert, 1995; Wardle et al., 2004; Fageria et al., 2014). In Inceptisols, Oxisols, Alfisols, and Ultisols, the recommended rate of $\mathrm{P}_{2} \mathrm{O}_{5}$ for rice production is up to $60 \mathrm{~kg} \mathrm{ha}^{-1}$ (Fageria et al., 2015; Bijay-Singh and Singh, 2017). Due to the increasing demand of inorganic $\mathrm{P}$ fertilizer in agriculture, we are depleting our future's P reserve quota (Ayoub, 1999) in the anticipated scenario of global P production peak by 2033 (Cordell et al., 2009) and potential phosphate crisis by 2050 (Gilbert, 2009). In this anticipated P crisis in the near future, there is no substitution of $\mathrm{P}$ in agriculture. Under these circumstances, the strategies for $\mathrm{P}$ management in agriculture must focus on minimization of quantity of applied-P (Richardson et al., 2009), possibility of recycling (Ashley et al., 2011), and the rhizosphere-based P management through innovative method of $\mathrm{P}$ application (Martínez et al., 2015). In the past two decades, significant progresses have been made in understanding the soil, rhizosphere, and plant processes associated with soil P-transformation, -mobilization, -acquisition, and -deficiency responses, etc. (Faucon et al., 2015). These findings indicated that specific recommendation for P placement either as broadcast or band methods are difficult, because the $\mathrm{P}$ application method and its placement choices are dependent on soil type and growing condition. Application method can offset the effects of $\mathrm{P}$ fixation by soils and increase P efficiency. So, there is a need to develop P application method, which can support better root architecture at the early stage of crop growth for exploration of more soil volume and thereby enhancing more nutrient uptake. Increase of tissue $\mathrm{P}$ concentration at seedling stage can lead to better root development. Dipping of rice roots in single superphosphate (SSP)-soil slurry just before transplanting can save P-fertilizer up to $40-60 \%$ of the recommended $\mathrm{P}$ dose applied in conventional practice and increases PUE and PRE (Ru-kun et al., 1982; Hooper, 1991; Balasubramanian et al., 1995; Talukdar et al., 2001). Lu et al. (1982) reported that the dipping of rice seedling roots in fertile soil or compost and water slurry in definite proportion (1:1 to $1: 5)$ enhances rice yield. These past findings though confirmed the usefulness of root dipping methods of $\mathrm{P}$ application for higher PUE and the requirement of reduced quantity of applied-P; a few questions pertaining to this method remains to be answered. For example, none of the past studies indicated the optimum $\mathrm{P}$ concentration and incubation duration for dipping of rice seedling roots in SSP added soil-water slurry method of P application (hereafter referred as SRD in SSP Soil Slurry). With this background, this study aimed to determine the optimum P concentration and incubation duration for SRD in SSP Soil Slurry method of $\mathrm{P}$ application and evaluate comparative efficiency of this method in presence or absence of phosphate 
solubilising bacteria (PSB) and broadcast method of $\mathrm{P}$ application in field condition.

\section{Materials and Methods}

\subsection{Experimental location and description of soil}

In order to determine the critical dose of $\mathrm{P}$ and the optimum incubation duration for dipping of rice seedling roots, two separate incubation experiments were carried out in the laboratory. An acid soil from a rice field on hilly terrace in the experimental farm located in the college of Post Graduate Studies, CAU (Imphal), Umiam was considered. The experimental farm is situated on the mid hill altitude of humid subtropics of Eastern Indian Himalayas. The soil is strongly acidic (pH 4.3) and categorized as infertile acid soil (Table 1). Soil was collected from $0-15 \mathrm{~cm}$ depth for use in the incubation experiments. Following the determina- tion of critical P dose and the optimum incubation duration for SRD in SSP Soil Slurry method (explained in the subsequent paragraphs), fields trials were conducted at two different locations. Field experiment-I was conducted in the above mentioned infertile rice field and field experiment-II in an acid soil of fertile rice field located in Athokpam Awang Leikai, Thoubal, Manipur, India (Table 1). The aim of the two field experiments was to evaluate the performance of the SRD in SSP Soil Slurry method in terms of enhancing P nutrition of transplanted seedlings at the vegetative growth stage and grain yield of rice under both infertile and fertile field conditions. The transplanted winter (kharif) rice crop was grown in the year 2014 and the high yielding variety Shahsarang was used for Field experiment-I and Arize (hybrid 6444 Gold) was used for field experiment-II. The composite soil samples ( 5 nos. from an area of $0.5 \mathrm{ha}$ ) from experimental rice fields were analyzed for physico-chemical and biological properties (Table 1).

Table 1. Origin, management history and physico-chemical and biological attributes of soils from field experimental sites.

\begin{tabular}{|c|c|c|c|}
\hline Soil attributes & Experiment site-I & Experiment site-II & Standard procedures described by Page et al. (1982) \\
\hline Origin & $\begin{array}{l}\text { CPGS experimental } \\
\text { farm field, Umiam }\end{array}$ & $\begin{array}{l}\text { Athokpam Awang } \\
\text { Leikai, Thoubal }\end{array}$ & \\
\hline Geographic location & $\begin{array}{l}25^{\circ} 40^{\prime} \mathrm{N}, 91^{\circ} 54^{\prime} \mathrm{E} \\
950 \mathrm{~m} \text { above } \mathrm{msl}\end{array}$ & $\begin{array}{l}24^{\circ} 37^{\prime} \mathrm{N}, 94^{\circ} 00^{\prime} \mathrm{E} \\
777 \mathrm{~m} \text { above } \mathrm{msl}\end{array}$ & \\
\hline Management history & Rice monocropping & Rice monocropping & \\
\hline Soil pH & 4.31 & 5.56 & 1:2.5 soil:water suspension by glass electrode \\
\hline Soil Texture & Sandy clay loam & Clay loam & Hydrometer method (Bouyoucos, 1927) \\
\hline$\%$ Sand & 62.1 & 29.9 & \\
\hline$\%$ Silt & 15.5 & 32.5 & \\
\hline$\%$ Clay & 22.4 & 37.6 & \\
\hline Bulk density $\left(\mathrm{g} \mathrm{cm}^{-3}\right)$ & 1.36 & 1.28 & Core method (Day, 1965) \\
\hline Organic carbon $\left(\mathrm{g} \mathrm{kg}^{-1}\right)$ & 14.5 & 18.1 & Dichromate wet oxidation method \\
\hline $\begin{array}{l}\text { Soil available nitrogen } \\
\left(\mathrm{mg} \mathrm{kg}^{-1} \text { soil) }\right.\end{array}$ & 95 & 215.0 & Alkaline permanganate method \\
\hline $\begin{array}{l}\text { Soil available phosphorus } \\
\left(\mathrm{mg} \mathrm{kg}^{-1}\right)\end{array}$ & 2.99 & 5.36 & Bray's-I extractant followed by $\mathrm{SnCl}_{2}$ blue colour method \\
\hline $\begin{array}{l}\text { Exchangeable } \mathrm{Ca}+\mathrm{Mg} \\
\left(\mathrm{meq} 100^{-1} \mathrm{~g} \text { soil) }\right.\end{array}$ & 1.5 & 110 & Versenate titration method \\
\hline $\begin{array}{l}\text { Exchangeable acidity } \\
\left.\text { (meq } 100^{-1} \mathrm{~g} \text { soil }\right)\end{array}$ & 2.2 & 0.2 & Neutral normal $\mathrm{KCl}$ extractant \\
\hline $\begin{array}{l}\text { Readily soluble } \mathrm{Al} \\
\left(\mathrm{mg} \mathrm{kg}^{-1} \text { soil }\right)\end{array}$ & 95 & 0.06 & Pyrocatechol violet method \\
\hline $\begin{array}{l}\text { Microbial biomass carbon } \\
\left(\mu g^{-1} \text { soil }\right)\end{array}$ & 205 & 561 & $\begin{array}{l}\text { Chloroform-fumigation-extraction method (Brookes and } \\
\text { Joergensen, 2006) }\end{array}$ \\
\hline
\end{tabular}




\subsection{Raising of rice seedlings for incubation experiments}

Seedlings of winter (Kharif) rice (HYV: Shahsarang) were raised on the seedling bed using infertile acid soil from hill terrace rice field. The raised seedling bed was prepared by uniformly mixed soil layer (bed size $2 \mathrm{~m}$ length $\mathrm{x} 0.7 \mathrm{~m}$ width $\times 15 \mathrm{~cm}$ height). Soil moisture in the seedling bed was maintained at $30 \% \mathrm{w}$ $\mathrm{v}^{-1}$. An amount of $2 \mathrm{~kg}$ finely ground well decomposed farm yard manure (FYM, contains $0.5 \% \mathrm{~N}, 0.2 \% \mathrm{P}_{2} \mathrm{O}_{5}$ and $0.5 \% \mathrm{~K}_{2} \mathrm{O}$ ) was applied on seedling bed 7 days prior to seed sowing. Application of FYM was essential to support the growth of healthy rice seedlings. No inorganic fertilizer was applied in the seeding bed. Twenty (21) days old uniform seedlings were uprooted and roots were washed under running tap water. These uniform fresh rice seedlings were used in the incubation experiments for determination of the critical P dose and the optimum incubation duration for SRD in SSP Soil slurry method.

\subsection{Incubation experiment-I: the critical P dose for SRD in SSP Soil Slurry}

Altogether 54 plastic beakers (cap. $500 \mathrm{ml}$ ) were arranged to impose 9 levels of $\mathrm{P}$ doses $(0,25,50,75$, $100,125,150,175$, and $200 \mathrm{mg} \mathrm{P} \mathrm{kg}^{-1}$ soil) as SSP and each level had 6 replicate beakers. Bulk quantity of soil from hill terrace rice field was collected, air dried and sieved (1 mm opening). The sieved soil (100 g) was distributed to each beaker and $40 \mathrm{ml}$ water was added to make soil-water slurry (2.5:1). In each beaker, roots of 10 seedlings were dipped for $12 \mathrm{~h}$ at $28 \pm 1{ }^{\circ} \mathrm{C}$ maintained inside an environment controlled greenhouse. After incubation, rice seedlings were taken out, roots were cleaned under running tap water, and then washed in $0.01 \mathrm{~N} \mathrm{HCl}$ followed by several washings with de-ionized water and oven-dried at $65^{\circ} \mathrm{C}$ to constant weight. Dried seedlings (inclusive of roots) were ground in Willey Mill and digested in a mixture of $\mathrm{HNO}_{3} / \mathrm{HClO}_{4}$ (3:1), and concentration of $\mathrm{P}$ was determined by the ammonium metavanadate procedure for colour development followed by absorbance read using double-beam spectrophotometry (Thermo Scientific, USA). Available P (AvlP) content in SSP Soil slurry was also determined. The P concentration and uptake curve against graded doses of slurry P was drawn and the critical concentration of $\mathrm{P}$ dose was determined as per procedure described by Cate and Nelson (1971).

\subsection{Incubation experiment-II: the optimum duration for SRD in SSP Soil Slurry}

Soil-water slurry was prepared similar to the procedure described for the incubation experiment-I. Altogether 42 plastic beakers (cap. $500 \mathrm{ml}$ ) were arranged to impose 7 time intervals $(0,4,8,12,16,20$ and 24 h) of incubation duration and 6 replicate beakers were maintained for each time interval. In this experiment, the critical dose of $\mathrm{P}\left(112.5 \mathrm{mg} \mathrm{P}_{2} \mathrm{O}_{5} \mathrm{~kg}^{-1}\right.$ soil as determined from the experiment-I) was uniformly applied to all beakers. In each beaker, roots of 10 seedlings (21 days old) were dipped and incubated at $28 \pm 1^{\circ} \mathrm{C}$ inside an environment controlled greenhouse. At each time interval, rice seedlings from 6 replicate beakers were taken out and processed similar to that described in the experiment-I. Finally, the P concentration and uptake curve against time intervals was drawn and the optimum duration for SRD in SSP Soil Slurry was determined as described above (Cate and Nelson, 1971).

\subsection{Field experiment}

The fields were remained under rice mono-cropping for last 5 years. For field experiment-I, the maximum and minimum temperature in study sites ranged from 
$20^{\circ} \mathrm{C}$ to $28^{\circ} \mathrm{C}$ and $6{ }^{\circ} \mathrm{C}$ to $18^{\circ} \mathrm{C}$ for field experimentI and $30{ }^{\circ} \mathrm{C}$ to $32{ }^{\circ} \mathrm{C}$ and $14{ }^{\circ} \mathrm{C}$ to $18{ }^{\circ} \mathrm{C}$ for field experiment-II and the relative humidity ranged from 75 to $83 \%$ during the experimental period for both sites. The soil properties of the rice fields are presented in Table 1.

In field experiment-I, the entire rice field was divided into 28 nos. uniform plots and each plot size was $20 \mathrm{sqm}(4 \mathrm{~m} \times 5 \mathrm{~m})$. Altogether 7 treatments were imposed in a completely randomized block design. The treatment combinations were: (1) control (no P application), (2) rock phosphate (RP) at $60 \mathrm{~kg} \mathrm{P}_{2} \mathrm{O}_{5}$ $\mathrm{ha}^{-1}$ (RP Broadcast), (3) single super phosphate (SSP) at $60 \mathrm{~kg} \mathrm{P}_{2} \mathrm{O}_{5} \mathrm{ha}^{-1}$ (SSP broadcast), (4) PSB (Enterobacter sp. strain MZS1-012) at $10^{8}$ cells per $\mathrm{g}$ inoculated root (PSB root-dip), (5) RP+PSB, (6) root-dip SSP Soil slurry method, and (7) root-dip SSP Soil slurry+RP+PSB. The PSB strain was originally isolated from rice rhizosphere collected from an acid Inceptisol. The pure culture of the strain was multiplied using Plate Count Broth for $24 \mathrm{~h}$ at $120 \mathrm{rpm}$ in an environmental shaker till the cell concentration attained $10^{9}$ cells per $\mathrm{ml}$ broth. The applied dose of RP was $30 \mathrm{~kg} \mathrm{P}_{2} \mathrm{O}_{5} \mathrm{ha}^{-1}$, when applied with other inputs. All treatment plots received $\mathrm{N}$ at $80 \mathrm{~kg} \mathrm{ha}^{-1}$ as urea and $\mathrm{K}_{2} \mathrm{O}$ at $40 \mathrm{~kg} \mathrm{ha}^{-1}$ as muirate of potash (MOP). Inorganic fertilizers were applied as basal (whole quantity of SSP and MOP and 1/3 quantity of urea as broadcast on puddle soil surface one day prior to transplantation). The remaining $2 / 3$ quantity of urea was applied in two equal splits: one at the active tillering stage and other one at the panicle initiation stage. The PSB biofertilizer (is a product of College of Post Graduate Studies, Central Agricultural University, Imphal) was applied at $4 \mathrm{~kg} \mathrm{ha}^{-1}$ as per seedling root-dip technique described previously for transplanted rice (Thakuria et al., 2009). Control plot received $\mathrm{N}$ and $\mathrm{K}_{2} \mathrm{O}$ but without $\mathrm{P}$. The stagnant water level $(5 \mathrm{~cm})$ was allowed in the plot till the grain filling stage. For SRD in
SSP Soil Slurry method, roots of rice seedlings were dipped in soil-water slurry (2.5:1) amended with SSP at $112.5 \mathrm{mg} \mathrm{P}_{2} \mathrm{O}_{5} \mathrm{~kg}^{-1}$ soil for $10 \mathrm{~h}$ and then the treated seedlings were transplanted. Plant protection measures were taken as and when required as per standard recommended practice.

Field experiment-II, only two treatments were imposed: (1) the conventional method of $\mathrm{P}$ management (recommended farmers' practice i.e. $\mathrm{N} / \mathrm{P}_{2} \mathrm{O}_{5} / \mathrm{K}_{2} \mathrm{O}$ at 80:60:40 $\mathrm{kg} \mathrm{ha}^{-1}$ as urea, SSP and MOP) and (2) SRD in SSP soil slurry+PSB+RP (seedling root dipping in soil slurry amended with $\mathrm{SSP}$ at $112.5 \mathrm{mg} \mathrm{P}_{2} \mathrm{O}_{5} \mathrm{~kg}^{-1}$ soil for $10 \mathrm{~h}$ followed by root-dipping for $1 \mathrm{~h}$ in PSB slurry as described above and RP at $30 \mathrm{~kg} \mathrm{P}_{2} \mathrm{O}_{5} \mathrm{ha}^{-1}$ as broadcast). In treatment 2, urea and MOP were applied similar to the quantities applied in treatment 1 . Rest of the operations (water management, pest and disease management, etc.) were performed similar to that described for Field experiment-I.

Twenty hills per plot were marked for recording plant parameters. Of the 20 marked hills, 10 hills were uprooted by digging $0.125 \mathrm{~m}^{3}$ soil block hill-1 ${ }^{-1} 50 \mathrm{~cm} \mathrm{~L}$ x $50 \mathrm{~B}$ x $50 \mathrm{~cm} \mathrm{H}$ ) and kept under water overnight to loosen the adhered soils. Then roots were washed carefully under running water and root portion of each hill was separated. The washed root system was wiped with blotting paper to remove additional free water and then root volume hill ${ }^{-1}$ was determined by volume-displacement techniques involving suspending roots in a clear graduated glass cylinder to observe the volume displacement (Harrington et al., 1994). For experiment-I and -II, root volume and effective tiller no. were determined at 60 DAT and 45 DAT, respectively. In field experiment-II, shoot and root portion of the uprooted hill were further processed for nutrient content analysis. In field experiment-I, grain and straw were separated for each of 10 marked plants at harvest and subjected to nutrient content analysis. For nutrient content analysis, plant samples 
were sun-dried and washed with $0.01 \mathrm{~N} \mathrm{HCl}$ followed 4 rinses with distilled water. Finally, the cleaned straw and grain were oven-dried at $65{ }^{\circ} \mathrm{C}$ to a constant weight. The oven dried grain and straw samples were ground in a Willey Mill for analysis of tissue P concentration and uptake. To record grain, straw and biological yield on plot basis, net plot area was harvested leaving the border row plants. The number of hills per harvested area was recorded for conversion of grain and straw yield per hectare basis. The biological yield (grain yield + straw yield) was recorded and then harvest index (HI) was reported as the ratio of grain yield and biological yield multiplied by 100 .

Uptake of $\mathrm{P}$ in biomass (root plus straw for pot experiment), straw and grain was determined by multiplying $\mathrm{P}$ content (\%) with their corresponding yield data. $\mathrm{P}$ use efficiency (PPE) and P recovery efficiency (PRE) were calculated as described by and Manoj-Kumar et al. (2012).

$$
\text { PUE }=\frac{\text { Total grain yield }\left(\mathrm{kg} \mathrm{ha}^{-1}\right)}{\text { Fertilizer applied }\left(\mathrm{kg} \mathrm{ha}^{-1}\right)}
$$
PRE $=\frac{\text { Total uptake from fertilized plot }\left(\mathrm{kg} \mathrm{ha}^{-1}\right)-\text { Total uptake from control plot }\left(\mathrm{kg} \mathrm{ha}^{-1}\right)}{\text { Fertilized applied }\left(\mathrm{kg} \mathrm{ha}^{-1}\right)}$

\subsection{Soil and plant tissue analysis}

Five soil cores (0-15 cm depth) per plot were pooled together to make 1 composite soil sample per plot at the harvest time for field experiment-I and at 45 DAT for field experiment-II. The half split of each composite sample was stored immediately at $4{ }^{\circ} \mathrm{C}$ in laboratory for acid-phosphomoesterase activity (PHA) determination by standard protocol (Tabatabai and Bremner, 1969). The other half split was air-dried and analyzed for $\mathrm{pH}$ and soil available $\mathrm{P}(\mathrm{AvlP})$ as per the standard methods (Table 1). For determination of tissue $\mathrm{P}$ content, plant sample was digested by using diacid mixture $\left(\mathrm{HNO}_{3}+\mathrm{HClO}_{4}\right)$ in 3:1 ratio and developed yellow colour using vanadomolybdo-phosphoric acid reagent. The uptake of $\mathrm{P}$ in biomass, straw and grain was determined by multiplying P content (\%) with their corresponding yield data.

\subsection{Statistical analysis}

All statistical analyses were performed using SPSS v. 12.0 (SPSS Inc. Chicago, IL, USA). For every parameter reported in this investigation, the six nutrient management treatments were analyzed for differences among means $(P<0.05)$ by performing one-way analysis of variances (ANOVA) and the Tukey's Honestly Significance Difference test at $P \leq 0.05$ for pair-wise comparisons among treatment means. For field experiment-II, paired t-test $(P \leq 0.05)$ was performed to test the significance difference between treatment means.

\section{Results}

\subsection{The critical dose of P for SRD in SSP Soil slurry}

The dry weight of 21 days old seedlings ranged from 0.97 to $1.02 \mathrm{~g}$ per seedling and they were statistically comparable ( $P>0.05$, one-way ANOVA). In incubation experiment-I, dry biomass $\mathrm{P}$ content and uptake of seedlings increased with the increasing doses of $\mathrm{P}$ and reached the maximum tissue $\mathrm{P}$ content $(0.50 \%)$ and uptake (5.0 $\mathrm{mg} \mathrm{P} \mathrm{g}^{-1}$ dry biomass) at the dose 125 $\mathrm{mg} \mathrm{P} \mathrm{kg}{ }^{-1}$ soil (Figure 1A). Increase in $\mathrm{P}$ doses beyond $125 \mathrm{mg} \mathrm{P} \mathrm{kg}^{-1}$ soil decreased biomass $\mathrm{P}$ content and uptake of rice seedlings. The maximum biomass $\mathrm{P}$ content and uptake of rice seedlings at the P dose 125 $\mathrm{mg} \mathrm{P} \mathrm{kg}{ }^{-1}$ soil was significantly higher compared to 
that in other $\mathrm{P}$ doses $(P<0.05)$, except the next higher dose (150 mg $\mathrm{P} \mathrm{kg}{ }^{-1}$ soil). The critical $\mathrm{P}$ dose from the Cate and Nelson curve was found to be $112.5 \mathrm{mg}$ $\mathrm{P} \mathrm{kg}^{-1}$ soil at $90 \%$ of the maximum relative $\mathrm{P}$ content and uptake (Figure 1B). The content of soil AvlP in SSP Soil slurry after $12 \mathrm{~h}$ incubation was significantly varied among graded $\mathrm{P}$ doses $(P<0.05$, Figure $2 \mathrm{~A})$.
The lowest content of soil AvlP was in the SSP Soil slurry without $\mathrm{P}$ dose (control) and then AvlP content increased with the increasing $\mathrm{P}$ dose and reached a threshold value at the dose $125 \mathrm{mg} \mathrm{P} \mathrm{kg}^{-1}$ soil (Figure 2A). The differences in the content of soil AvlP among $\mathrm{P}$ doses at $125 \mathrm{mg} \mathrm{P} \mathrm{kg}^{-1}$ soil and above were non-significant $(P>0.05$, Figure $2 \mathrm{~A})$.

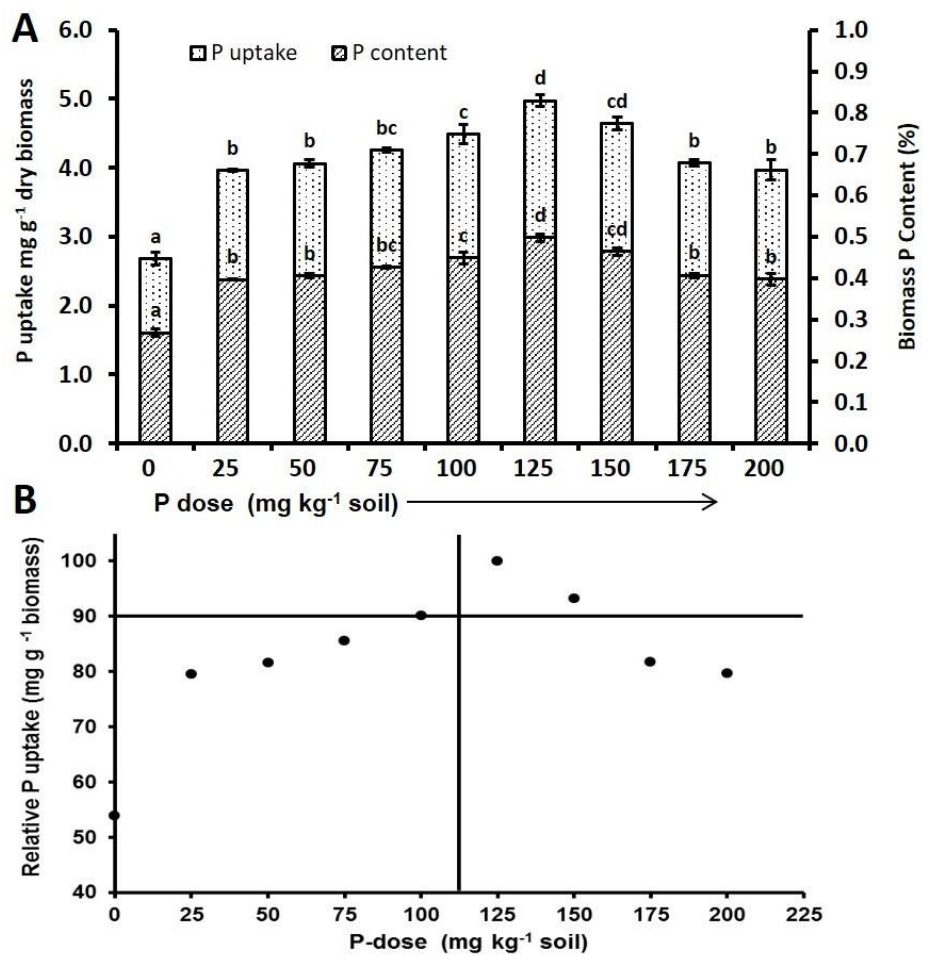

Figure 1. Effect of graded doses of orthophosphate (as SSP) in soil:water slurry on (A) the content and uptake of $\mathrm{P}$ in dry biomass of rice seedlings (HYV: Shahsarang, 21 days old) in response to root dipping for a duration of $12 \mathrm{~h}$, and (B) the critical curve of $\mathrm{P}$ application dose deduced based on the relative $\mathrm{P}$ uptake, as proposed by Cate and Nelson (1971) in biomass of rice seedlings. Each point on the curve represents the mean of 6 replicates. 


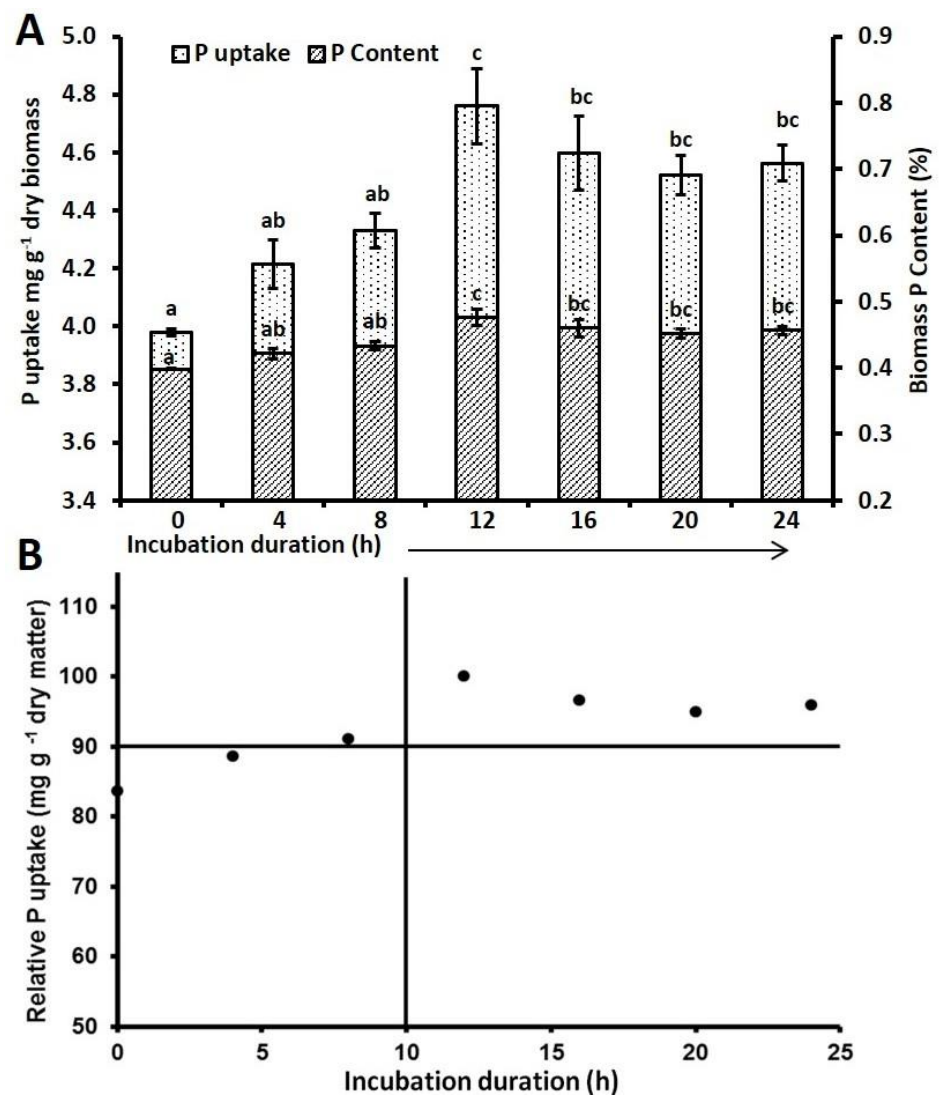

Figure 2. Effect of incubation duration (from 0 to $24 \mathrm{~h}$ at $4 \mathrm{~h}$ interval) on (A) the content and uptake of $\mathrm{P}$ in dry biomass of rice seedlings (HYV: Shahsarang, 21 days old) in response to root dipping in soil:water slurry amended with SSP (-112.5 $\mathrm{mg} \mathrm{P} \mathrm{kg}^{-1}$ soil), and (B) the critical curve of incubation duration deduced based on the relative P uptake, as proposed by Cate and Nelson (1971) in biomass of rice seedlings. Each point on the curve represents the mean of 6 replicates.

3.2. The optimum incubation duration for SRD in SSP Soil Slurry

In the incubation experiment-II, the critical concentration (112.5 $\mathrm{mg} \mathrm{P} \mathrm{kg}^{-1}$ soil) obtained from the incubation experiment-I was applied uniformly to soil slurry for different incubation duration (ranged from 0 to 24 $\mathrm{h}$ at an interval of $4 \mathrm{~h}$; Figure $3 \mathrm{~A}$ ). The dry biomass $\mathrm{P}$ content and uptake increased with the increasing incubation duration and reached the maximum $\mathrm{P}$ content (0.48\%) and uptake (4.76 $\mathrm{mg} \mathrm{P} \mathrm{g}^{-1}$ dry biomass) at $12 \mathrm{~h}$ duration. Afterwards increase in incubation duration decreased biomass $\mathrm{P}$ content and uptake, but differences were not statistically significant (Figure $3 \mathrm{~A})$. The maximum biomass $\mathrm{P}$ content and uptake in rice seedlings at $12 \mathrm{~h}$ incubation duration was signifi- 
cantly higher compared to that in incubation duration lesser than $12 \mathrm{~h}(P<0.05$, Figure 3A). The critical incubation duration from the Cate and Nelson curve was found to be $10 \mathrm{~h}$ at $90 \%$ of the maximum relative P content and uptake (Figure 3B). Soil AvlP content was the highest in SSP Soil Slurry at $0 \mathrm{~h}$ and then decreased with increasing incubation duration and reached the lowest content at $12 \mathrm{~h}$. Afterward soil AvlP content slightly increased with higher incubation duration, but the difference was non-significant with $12 \mathrm{~h}$ incubation duration $(P>0.05$, Figure $2 \mathrm{~B})$.
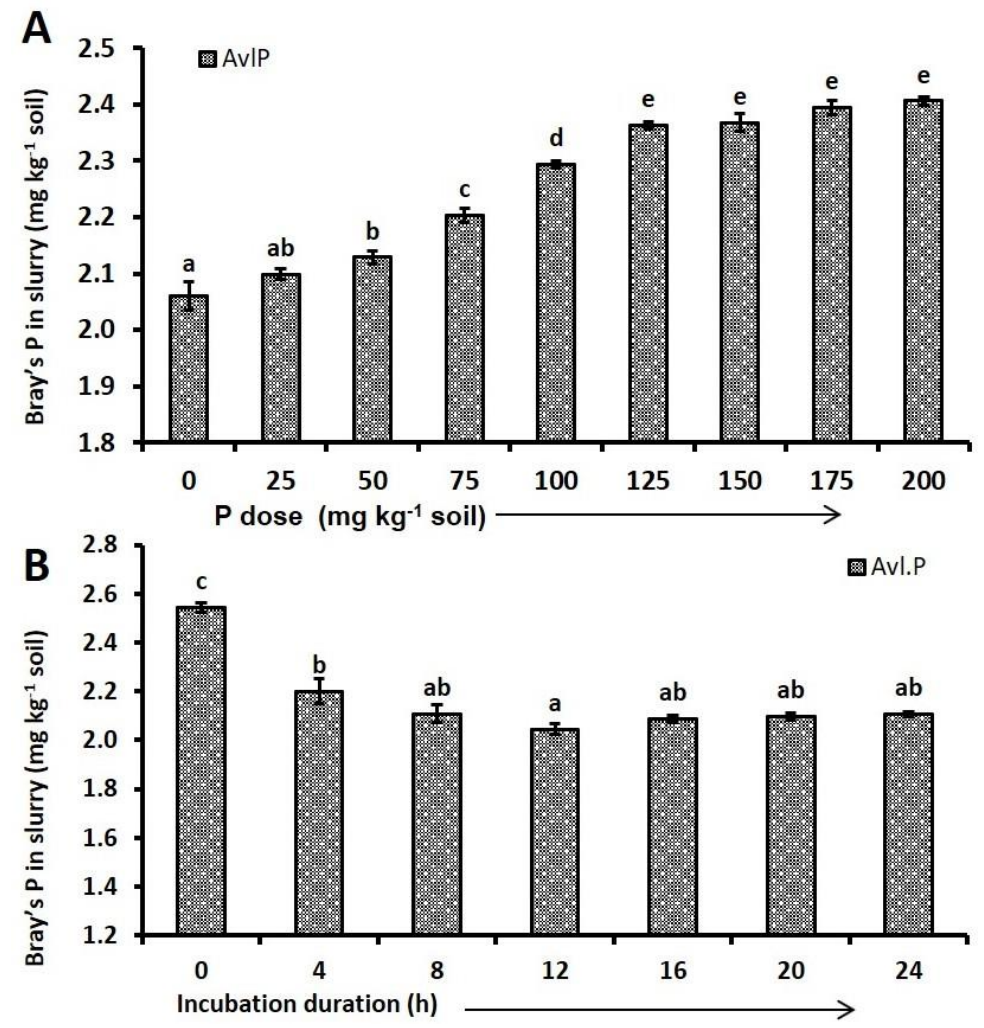

Figure 3. The content of soil available P (AvlP) in soil:water slurry after root dipping of rice seedling (HYV: Shahsarang, 21 days old), (A) along the graded doses of orthophosphate (as SSP) for $12 \mathrm{~h}$ and (B) incubation duration (from 0 to $24 \mathrm{~h}$ at $4 \mathrm{~h}$ intervals) in soil:water slurry amended with SSP (112.5 mg P kg-1 soil). Mean values (columns) with different letters indicate statistically significant difference at $P<0.05$, as determined by one-way ANOVA incorporating Tukey's Honestly Significance Difference for multiple pair-wise comparisons. Each value (column) represents the average of 6 replicate measurements. 


\subsection{Performance of SRD in SSP Soil Slurry method in field conditions}

\subsubsection{Field experiment-I in infertile acid soil}

Application of $\mathrm{P}$ by different methods to transplanted rice crop positively influenced the growth and yield parameters (number of effective tillers and root volume at 60 DAT, grain yield, straw yield, biological yield and harvest index), and the differences between application methods in terms of these parameters were significant $(P<0.05$, Table 2). The maximum number of effective tillers produced in SSP root dip+PSB+RP applied plots followed by the comparable numbers in SSP-root-dip plots and SSP broadcast plots (Table 2). The maximum root volume was produced in SSP-root-dip+PSB+RP plots followed by the comparable root volume in SSP-root-dip plot and the significant lesser volume in SSP broadcast plots (Table 2). The effective number of tillers and root volume of rice in $\mathrm{PSB}+\mathrm{RP}$ treated plots were comparable with that in SSP broadcast plot $(P>0.05)$, but sig- nificantly lesser than that in SSP-root-dip and SSP-rootdip+PSB+RP treated plots $(P<0.05$; Table 2$)$. Grain, straw and biological yields were significantly higher in all $\mathrm{P}$ treated plots compared to that in no $\mathrm{P}$ input control plots $(P<0.05$, Table 2$)$. The highest grain yield achieved was in SSP-root-dip+PSB+RP plots, and the grain yield between SSP broadcast plots and SSP root-dip+PSB+RP plots were comparable $(P>0.05)$. The increase in grain yield over control (no P input) plot was in order of SSP root-dip+PSB+RP $(55.4 \%)>$ SSP $(52.9 \%)>$ SSP-root$\operatorname{dip}(47.8 \%)>\mathrm{PSB}+\mathrm{RP}(32.5 \%)>\mathrm{PSB}(12.1 \%)>\mathrm{RP}$ $(8.3 \%)$. The straw and biological yield was significantly higher in SSP broadcast plot compared to all other treatment plots $(P<0.05)$, except SSP-root-dip+PSB+RP and SSP-root-dip plots that produced comparable straw and biological yields $(P>0.05$, Table 2$)$. Harvest index of rice was the highest in SSP-root-dip+PSB+RP plots, which was comparable to that in SSP-root-dip, $\mathrm{PSB}+\mathrm{RP}$, and SSP broadcast plots $(P>0.05$, Table 2). The harvest index of rice was significantly lesser in control and RP broadcast plots than that in other P treated plots.

Table 2. Growth and yield of rice crop (variety: Shahsarang) as influenced by phosphorus management methods in strongly acid infertile soil from field experiment-I.

\begin{tabular}{|c|c|c|c|c|c|c|c|}
\hline P management methods & $\begin{array}{l}\text { No. of } \\
\text { effective } \\
\text { tiller per hill }\end{array}$ & $\begin{array}{l}\text { Root } \\
\text { Volume } \\
\left(\mathrm{ml} \mathrm{hill}^{-1}\right)\end{array}$ & $\begin{array}{l}\text { Grain yield } \\
\left(\mathrm{t} \mathrm{ha}^{-1}\right)\end{array}$ & $\begin{array}{l}\text { Increase in } \\
\text { grain yield } \\
\text { over } \\
\text { control }(\%)\end{array}$ & $\begin{array}{l}\text { Straw yield } \\
\left(\mathrm{t} \mathrm{ha}^{-1}\right)\end{array}$ & $\begin{array}{l}\text { Biological } \\
\text { yield } \\
\left(\mathrm{t} \mathrm{ha}^{-1}\right)\end{array}$ & $\begin{array}{l}\text { Harvest } \\
\text { Index }\end{array}$ \\
\hline Control (no P input) & $13.0 \pm 0.41 \mathrm{a}$ & $75.2 \pm 4.5 \mathrm{a}$ & $1.57 \pm 0.05 \mathrm{a}$ & - & $2.56 \pm 0.07 \mathrm{a}$ & $4.13 \pm 0.12 \mathrm{a}$ & $0.38 \pm 0.004 a$ \\
\hline RP Broadcast & $14.0 \pm 0.41 \mathrm{a}$ & $77.0 \pm 2.0 \mathrm{a}$ & $1.70 \pm 0.04 \mathrm{~b}$ & 8.3 & $2.68 \pm 0.08 \mathrm{a}$ & $4.38 \pm 0.12 \mathrm{a}$ & $0.39 \pm 0.005 \mathrm{ab}$ \\
\hline SSP Broadcast & $18.5 \pm 0.65 \mathrm{bc}$ & $107.0 \pm 5.5 \mathrm{bc}$ & $2.40 \pm 0.06 \mathrm{de}$ & 52.9 & $3.38 \pm 0.09 \mathrm{c}$ & $5.78 \pm 0.15 \mathrm{c}$ & $0.42 \pm 0.003 \mathrm{~cd}$ \\
\hline PSB & $14.8 \pm 0.48 \mathrm{a}$ & $84.9 \pm 3.2 \mathrm{ab}$ & $1.76 \pm 0.04 \mathrm{ab}$ & 12.1 & $2.58 \pm 0.09 \mathrm{a}$ & $4.34 \pm 0.13 \mathrm{a}$ & $0.40 \pm 0.006 b c$ \\
\hline $\mathrm{PSB}+\mathrm{RP}$ & $16.6 \pm 0.25 \mathrm{ab}$ & $91.6 \pm 3.5 \mathrm{ab}$ & $2.08 \pm 0.05 \mathrm{c}$ & 32.5 & $2.87 \pm 0.07 \mathrm{ab}$ & $4.95 \pm 0.11 \mathrm{~b}$ & $0.42 \pm 0.004 \mathrm{~cd}$ \\
\hline SSP Root Dip & $19.0 \pm 0.41 \mathrm{c}$ & $127.5 \pm 7.8 \mathrm{~cd}$ & $2.32 \pm 0.03 \mathrm{~d}$ & 47.8 & $3.08 \pm 0.10 \mathrm{bc}$ & $5.40 \pm 0.13 \mathrm{bc}$ & $0.43 \pm 0.004 \mathrm{~d}$ \\
\hline SSP Root Dip + PSB + RP & $19.6 \pm 0.45 c$ & $134.3 \pm 8.6 \mathrm{~d}$ & $2.44 \pm 0.03 \mathrm{e}$ & 55.4 & $3.04 \pm 0.06 \mathrm{bc}$ & $5.48 \pm 0.05 b c$ & $0.45 \pm 0.006 \mathrm{~d}$ \\
\hline
\end{tabular}

Values are means \pm standard errors. Within a column, values followed by different letters indicate statistically significant difference at $P \leq 0.05$, one-way ANOVA incorporating Tukey's Honestly Significant Difference for multiple pair-wise comparisons. $\mathrm{RP}$ - rock phosphate; SSP - Single super phosphate; PSB - Phosphate solubilising bacteria. 
The content and uptake of $\mathrm{P}$ in grain and straw of rice were significantly higher in SSP-root-dip $+\mathrm{PSB}+\mathrm{RP}$ plots than that in other $\mathrm{P}$ treatments $(P<0.05$, Table 3). The second highest $P$ content and uptake in grain and straw of rice were in SSP broadcast plot and were significantly higher than that in rest of the $\mathrm{P}$ treatments $(P<0.05)$.
At harvest, soil AvlP content was the highest in $\mathrm{PSB}+\mathrm{RP}$ plots followed by the comparable $\mathrm{P}$ content in RP broadcast plots and SSP-root-dip+PSB+RP plots $(P>0.05$, Table 3$)$. Soil AvlP contents between PSB alone plots and SSP-root-dip plots were comparable, but these values were significantly lesser than that in RP broadcast plots, SSP-root-dip+PSB+RP plots, and PSB+RP plots $(P<0.05$, Table 3$)$.

Table 3. Phosphorus content and uptake in grain and straw of rice crop (variety: Shahsarang) as influenced by phosphorus management methods in a strongly acid infertile soil from field experiment-I.

\begin{tabular}{|c|c|c|c|c|c|c|}
\hline$P$ management methods & $\begin{array}{l}\text { P content in } \\
\text { grain } \\
(\%)\end{array}$ & $\begin{array}{l}\text { P uptake } \\
\text { in grain } \\
\left(\mathrm{kg} \mathrm{ha}^{-1}\right)\end{array}$ & $\begin{array}{c}\text { P content in } \\
\text { straw } \\
(\%)\end{array}$ & $\begin{array}{l}\text { P uptake } \\
\text { in Straw } \\
\left(\mathrm{kg} \mathrm{ha}^{-1}\right)\end{array}$ & $\begin{array}{l}\text { AvlP } \\
\left(\mathrm{kg} \mathrm{ha}^{-1}\right)\end{array}$ & $\begin{array}{l}\text { PHA } \\
\left(\mu \mathrm{g} \mathrm{pNP} \mathrm{g}^{-1}\right. \\
\left.\text { soil h} \mathbf{h}^{-1}\right)\end{array}$ \\
\hline Control (no P input) & $0.187 \pm 0.002 \mathrm{a}$ & $1.30 \pm 0.03 \mathrm{a}$ & $0.049 \pm 0.006 \mathrm{a}$ & $3.37 \pm 0.09 \mathrm{ab}$ & $7.5 \pm 0.5 \mathrm{ab}$ & $251 \pm 10 \mathrm{a}$ \\
\hline RP Broadcast & $0.195 \pm 0.003 \mathrm{ab}$ & $1.65 \pm 0.05 \mathrm{~b}$ & $0.065 \pm 0.007 \mathrm{~b}$ & $3.07 \pm 0.16 \mathrm{a}$ & $9.5 \pm 0.5 \mathrm{bc}$ & $230 \pm 17 \mathrm{a}$ \\
\hline SSP Broadcast & $0.208 \pm 0.001 \mathrm{~b}$ & $2.74 \pm 0.05 \mathrm{~d}$ & $0.081 \pm 0.007 \mathrm{~d}$ & $4.98 \pm 0.14 \mathrm{~d}$ & $8.4 \pm 0.4 \mathrm{abc}$ & $239 \pm 12 \mathrm{a}$ \\
\hline PSB & $0.203 \pm 0.003 b$ & $1.99 \pm 0.09 \mathrm{c}$ & $0.077 \pm 0.009 \mathrm{c}$ & $3.56 \pm 0.04 \mathrm{~b}$ & $6.7 \pm 0.5 \mathrm{a}$ & $481 \pm 11 \mathrm{~d}$ \\
\hline $\mathrm{PSB}+\mathrm{RP}$ & $0.198 \pm 0.004 \mathrm{ab}$ & $2.13 \pm 0.03 \mathrm{c}$ & $0.074 \pm 0.008 \mathrm{c}$ & $4.12 \pm 0.08 \mathrm{c}$ & $10.6 \pm 0.8 \mathrm{c}$ & $420 \pm 13 c$ \\
\hline SSP Soil slurry & $0.198 \pm 0.003 b$ & $2.05 \pm 0.05 \mathrm{c}$ & $0.067 \pm 0.010 \mathrm{~b}$ & $4.35 \pm 0.05 \mathrm{c}$ & $6.6 \pm 0.9 \mathrm{a}$ & $359 \pm 19 b$ \\
\hline SSP Soil slurry+PSB+RP & $0.238 \pm 0.003 \mathrm{c}$ & $2.90 \pm 0.08 \mathrm{c}$ & $0.095 \pm 0.012 \mathrm{e}$ & $5.58 \pm 0.08 \mathrm{e}$ & $9.0 \pm 0.6 \mathrm{abc}$ & $349 \pm 15 b$ \\
\hline
\end{tabular}

Values are means \pm standard errors. Within a column, values followed by different letters indicate statistically significant difference at $P<0.05$, one-way ANOVA incorporating Tukey's Honestly Significant Difference for multiple pair-wise comparisons. $\mathrm{RP}$ - rock phosphate; SSP - Single super phosphate; PSB - Phosphate solubilising bacteria.

Soil PHA activity in control plots, RP broadcast plots, and SSP broadcast plots were comparable $(P>0.05$, Table 3) and these values were significantly lesser than that in PSB, PSB+RP, SSP-root-dip, and SSProot-dip+PSB+RP plots $(P<0.05)$. The highest PHA activity was in PSB plots, which was significantly higher than the $2^{\text {nd }}$ highest PHA activity in PSB+RP plots $(P<0.05$, Figure 3$)$. The PHA activity in SSProot-dip, and SSP-root-dip+PSB+RP plots were comparable $(P>0.05)$ and these values were significantly lesser than that in PSB plots and PSB + RP plots $(P<$ 0.05 , Figure 3$)$. Due to no addition of fertilizer inputs in PSB alone and control plots, PUE and PRE could not be calculated. Apart from PSB alone and control plots, there were significant differences among other treatment plots in terms of PUE and PRE $(P<0.05$; Figure 4). The PUE and PRE were the highest (2071 and 1.49, respectively) in SSP-root-dip plots followed by 78 and 0.13 , respectively in SSP-root-dip+PSB+RP plots. The PRE was found comparable between SSP broadcast and PSB+RP plots. The PUE was higher (69) in PSB+RP than that (40) in SSP broadcast and these values were significantly higher than that (28) in RP broadcast plots $(P<0.05$, Figure 4$)$. 


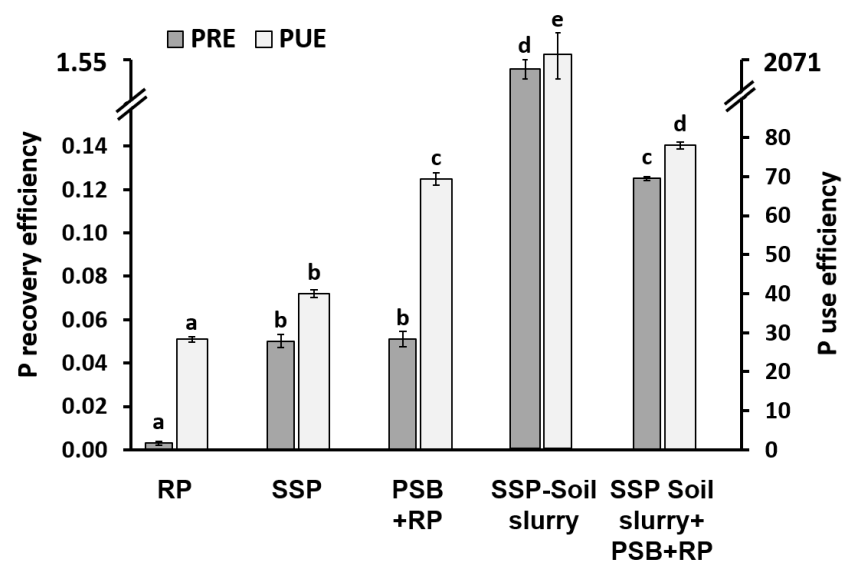

Figure 4. Effect of phosphorus management methods on P-use and -recovery efficiencies (PUE and PRE) of rice crop (var. Shahsarang) grown in acid Inceptisol ( $\mathrm{pH}$ 4.3) under field condition. Within a parameter (excluding Control, PSB and SSP Soil slurry treatments), mean values (columns) with different letters indicate statistically significant difference at $P \leq 0.05$, as determined by one-way ANOVA incorporating Tukey's Honestly significance difference for multiple pair-wise comparisons. Each value (dendrogram) represents the mean of 4 replicate measurements. Note: SSP Soil slurry showed exceptionally high PUE and PRE due to the addition of little quantity $(7.0 \mathrm{~kg})$ of SSP in soil:water slurry. The PUE and PRE were not calculated in control (no P input) and PSB plots due to no addition of external P inputs.

\subsubsection{Field experiment-II in fertile acid soil}

Rice grown under SSP-root-dip+PSB+RP plots and conventional $\mathrm{P}$ method plots produced comparable dry shoot weight hill ${ }^{-1}$ at 45 DAT and effective tiller no. hill ${ }^{-1}$ and no. of grains panicle ${ }^{-1}$ at harvest $(P>0.05$; Table 4$)$. Both nutrient management regimes were also comparable in terms of straw yield, but grain yield was significantly higher in SSP-root-dip+PSB+RP plots as compared to that in conventional P method plots (Table 4). Similarly, HI of rice was significantly higher in SSP-root-dip+PSB+RP plots than that in conventional P method plots (Table 4). The shoot and root $\mathrm{P}$ content and uptake at 45 DAT were comparable between SSP-root-dip+PSB+RP plots and conventional P method plots (Table 4).

Table 4. The comparative performance of SRD in SSP soil slurry+PSB+RP method relative to the conventional method of P management in terms of growth and yield of rice grown in a fertile acid soil under field experiment-II.

\begin{tabular}{|c|c|c|c|c|c|c|c|c|c|c|c|}
\hline \multirow[b]{2}{*}{$\begin{array}{l}\text { Nutrient } \\
\text { management } \\
\text { regimes }\end{array}$} & \multicolumn{6}{|c|}{ At 45 DAT } & \multicolumn{5}{|c|}{ At harvest } \\
\hline & $\begin{array}{c}\text { Shoot P } \\
\text { content } \\
(\%)\end{array}$ & $\begin{array}{c}\text { Root } \mathrm{P} \\
\text { content } \\
(\%)\end{array}$ & $\begin{array}{c}\text { Shoot P } \\
\text { uptake } \\
\left(\mathrm{kg} \mathrm{ha}^{-1}\right)\end{array}$ & $\begin{array}{c}\text { Root P } \\
\text { uptake } \\
\left(\mathrm{kg} \mathrm{ha}^{-1}\right)\end{array}$ & $\begin{array}{c}\text { Dry shoot } \\
\text { wt. } \\
\left(\mathrm{g} \mathrm{hill}^{-1}\right) \\
\end{array}$ & $\begin{array}{l}\text { Dry root } \\
\text { wt. } \\
\left(\mathrm{g} \mathrm{hill}^{-1}\right)\end{array}$ & $\begin{array}{c}\text { Effective } \\
\text { tiller no. } \\
\text { hill }^{-1}\end{array}$ & $\begin{array}{c}\text { No. of } \\
\text { grains } \\
\text { panicle } \\
\end{array}$ & $\begin{array}{l}\text { Grain } \\
\text { yield } \\
\left(\mathrm{t} \mathrm{ha}^{-1}\right)\end{array}$ & $\begin{array}{c}\text { Straw } \\
\text { yield } \\
\left(\mathrm{t} \mathrm{ha}^{-1}\right)\end{array}$ & $\begin{array}{l}\text { Harvest } \\
\text { Index }\end{array}$ \\
\hline $\begin{array}{l}\text { Conventional } \\
\text { method of } \mathrm{P} \\
\text { management }^{\text {a }}\end{array}$ & $0.31 \pm 0.02$ & $0.12 \pm 0.02$ & $28.7 \pm 3.42$ & $3.79 \pm 1$ & $28.2 \pm 2.52 \mathrm{a}$ & $9.40 \pm 1.21 \mathrm{a}$ & $14.4 \pm 1.00 \mathrm{a}$ & $150 \pm 7.3 \mathrm{a}$ & $5.63 \pm 0.22 \mathrm{a}$ & $7.52 \pm 0.58 \mathrm{a}$ & $0.43 \pm 0.01 \mathrm{a}$ \\
\hline $\begin{array}{l}\text { SRD in SSP soil } \\
\text { slurry+PSB+RP }\end{array}$ & $0.32 \pm 0.04$ & $0.14 \pm 0.03$ & $28.5 \pm 3.4$ & $4.26 \pm 1$ & $27.2 \pm 2.70 \mathrm{a}$ & $10.5 \pm 1.43 \mathrm{a}$ & $14.0 \pm 1.14 \mathrm{a}$ & $152 \pm 11.8 \mathrm{a}$ & $5.80 \pm 0.21 \mathrm{~b}$ & $7.11 \pm 0.18 \mathrm{a}$ & $0.45 \pm 0.01 \mathrm{~b}$ \\
\hline $\begin{array}{l}\text { Significance } \\
\text { (2-tailed) }\end{array}$ & ns & ns & ns & ns & 0.41 & 0.06 & 0.57 & 0.77 & 0.02 & 0.20 & 0.04 \\
\hline
\end{tabular}

\begin{tabular}{lllllllllll}
$\begin{array}{l}\text { Significance } \\
\text { (2-tailed) }\end{array}$ & $\mathrm{ns}$ & $\mathrm{ns}$ & $\mathrm{ns}$ & $\mathrm{ns}$ & 0.41 & 0.06 & 0.57 & 0.77 & 0.02 & 0.20 \\
\hline
\end{tabular}

Value represents mean \pm standard deviation $\left(\mathrm{n}=50\right.$ hills per treatment). ${ }^{\mathrm{a}} \mathrm{N} / \mathrm{P}_{2} \mathrm{O}_{5} / \mathrm{K}_{2} \mathrm{O}$ at $80: 60: 40 \mathrm{~kg}$ ha ${ }^{-1}$ as urea, $\mathrm{SSP}$ and $\mathrm{MOP}$.

${ }^{\mathrm{b}}$ Seedling root dipping in soil slurry amended with SSP at $112.5 \mathrm{mg} \mathrm{P}_{2} \mathrm{O}_{5} \mathrm{~kg}^{-1}$ soil for $10 \mathrm{~h}$ followed by root-dipping for $1 \mathrm{~h}$ in

PSB slurry and RP broadcast at $30 \mathrm{~kg} \mathrm{P}_{2} \mathrm{O}_{5} \mathrm{ha}^{-1}$ 


\section{Discussion}

Phosphorus management for crop production in acid soils needs refinement in order to reduce the application dose of phosphatic fertilizers with enhanced PUE and PRE in the anticipated scenario of the depletion of future's $\mathrm{P}$ reserve quota and the potential phosphate crisis globally by 2050 . To achieve this goal, this investigation developed a rhizopsheric phosphorus management method i.e. SRD in SSP soil slurry method and for which the critical dose of $\mathrm{P}$ and the optimum incubation duration were determined. The philosophy of this P management method is to feed rice seedlings with excess $\mathrm{P}$ so that early root growth can be supported on transplantation in a constrained environment like acid soils. Supporting root growth at the early establishment stages of a crop is one of the important strategies in the rhizosphere-based $\mathrm{P}$ management in problematic acid soils (Richardson et al., 2009). From the incubation experiment-I, it was evident that rice seedlings were able to take up $2.3 \mathrm{mg}$ of more $\mathrm{P}$ per $\mathrm{g}$ dry biomass at the $\mathrm{P}$ application dose 125 $\mathrm{mg} \mathrm{kg}{ }^{-1}$ soil in the soil:water slurry over control (Figure 1A). This excess quantity of $\mathrm{P}$ was taken up by rice seedlings within $12 \mathrm{~h}$ incubation duration. Thus, rice seedling possesses the ability to uptake excess $\mathrm{P}$ from a concentrated soil slurry and hence, SRD in SSP Soil slurry could be a valid P management technology. Phosphorus concentration in root cells of rice can be up to 1000-fold higher than the P concentration in soil solution (Ramaekers et al., 2010). Talukdar et al. (2001) using winter (Sali) rice (var. Ranjit) indicated that rice seedlings dipped in a mixture of SSP amended soil:water slurry (3.5:40:100) for $12 \mathrm{~h}$ incubation absorbed $0.69 \mathrm{mg}$ more $\mathrm{P}$ per g dry biomass than seedlings dipped in unamended soil:water slurry.
In our incubation experiment-I, biomass P content and uptake by rice was decreased beyond orthophosphate dose at $125 \mathrm{mg} \mathrm{kg}^{-1}$ soil. Rice seedlings may expose to a toxic level of Pi concentration beyond $125 \mathrm{ppm}$ dose. Lee et al. (1990) mentioned that when plants have an adequate supply of $\mathrm{P}_{\mathrm{i}}$ up to certain maximum concentration and are absorbing it at a rate that exceed demand, plant cell try to prevent the accumulation of toxic Pi concentrations through a number of processes like production of phytic acid within cell, reduction in rate of $\mathrm{P}_{\mathrm{i}}$ uptake from outside solution, $\mathrm{P}_{\mathrm{i}}$ loss by efflux, etc. (Bieleski and Ferguson, 1983). So, reduction in $\mathrm{P}$ content and uptake at higher doses of $\mathrm{P}$ concentration beyond $125 \mathrm{mg} \mathrm{kg}^{-1}$ soil was probably due to osmotic effects (Navarro et al., 2001). This study clearly revealed that the optimum dose of orthophosphate (in the form of SSP) in soil slurry rootdipping method is $112.5 \mathrm{mg} \mathrm{kg}^{-1}$ soil (Figure 2). This observation was applicable to the strongly acid Inceptisol (Sandy clay loam and pH 4.3). Soil AvlP in SSP amended soil-water slurry after completion of rootdipping (12 $\mathrm{h}$ incubation) also supported the uptake pattern of $\mathrm{P}$ in seedling biomass. The content of soil AvlP after $12 \mathrm{~h}$ incubation in higher $\mathrm{P}$ doses beyond the $\mathrm{P}$ dose $125 \mathrm{mg} \mathrm{kg}^{-1}$ soil didn't differ significantly with the content of soil AvlP content at P dose $125 \mathrm{mg}$ $\mathrm{kg}^{-1}$ soil. The P doses below $125 \mathrm{mg} \mathrm{kg}^{-1}$ soil, soil AvlP contents decreased significantly from the value of soil AvlP at $125 \mathrm{mg} \mathrm{kg}^{-1}$ soil $\mathrm{P}$ dose. These findings clearly revealed that higher $\mathrm{P}$ dose above $125 \mathrm{mg} \mathrm{kg}^{-1}$ soil in soil:water slurry (at least for sandy clay loam Inceptisol and $\mathrm{pH} 4.31$ ) didn't increase P uptake in rice seedling (HYV cultivar) indeed P uptake decreased.

Results from the incubation experiment-II indicated that the highest $\mathrm{P}$ content $(0.48 \%)$ and uptake (4.74 $\mathrm{mg} \mathrm{g}^{-1}$ dry biomass) of rice seedlings was achieved at $12 \mathrm{~h}$ incubation. The decrease in the content and uptake of $\mathrm{P}$ in rice seedlings was evident beyond 12 $\mathrm{h}$ incubation. The maximum content and uptake of 
$\mathrm{P}$ in rice seedlings in the incubation experiment-II were nearly matched with that (content $0.50 \%$ and $4.94 \mathrm{mg} \mathrm{P} \mathrm{g}^{-1}$ dry biomass) observed in the incubation experiment-I. It was clearly demonstrated that the optimum incubation duration for SRD in SSP Soil slurry method is $10 \mathrm{~h}$ by applying the approach of Cate and Nelson (1971). There is possibility that the optimum dose of orthophosphate (in the form of SSP) in soil:water slurry may vary depending upon the type of acid soils and rice cultivars which need to be ascertained through future research. This study reported the optimum dose of orthophosphate (112.5 $\mathrm{mg} \mathrm{kg}^{-1}$ soil) and the optimum incubation duration (10 h) for HYV rice cultivar treated in a sandy clay loam Inceptisol ( $\mathrm{pH} 4.3$ ).

In the field experiments, yield of rice was positively influenced due to different $P$ management methods and the increase of grain yield in SSP broadcast, $\mathrm{PSB}+\mathrm{RP}$, SSP-root-dip, and SSP-root-dip+PSB+RP plots over control (no P input) plots were $52.9 \%, 32.5 \%, 47.8$ $\%$, and $55.4 \%$, respectively (Table 2 ). The root volume (at 45 DAT) and grain yield of rice maintained a significant positive correlation $\left(\mathrm{r}=0.78^{* *}, \mathrm{n}-2=26\right)$ indicating the importance of root growth on grain yield. The higher root volume was in the order SSProot-dip $+\mathrm{PSB}+\mathrm{RP}>$ SSP-root-dip $>$ SSP broadcast $>$ $\mathrm{PSB}+\mathrm{RP}>\mathrm{PSB}>\mathrm{RP}$ broadcast $>$ control. There was significant positive correlation between root volume and grain $\mathrm{P}$ uptake or straw $\mathrm{P}$ uptake $\left(\mathrm{r}=0.77^{* *}\right.$ and $0.69^{* *}$, respectively; $n-2=26$ ). Findings clearly indicated that $\mathrm{P}$ management methods had played critical role in root growth and development at the early stage of crop growth. The P management methods i.e. SRD in SSP Soil slurry or SSP Soil slurry+PSB+RP supported higher $\mathrm{P}$ uptake during root-dipping just before transplantation, which subsequently helped in development of more vigorous root system during early establishment of plant in the main field. Higher P uptake in plants at the initial stage of crop growth provides an early advantage in root development (Chatterjee, 2005). The roots of rice seedlings after uprooting from nursery bed, when incubated overnight in SSP amended soil-water slurry, seedlings uptake maximum possible $\mathrm{P}$ which help them in development of robust root system at the early stage of crop growth (Talukdar et al., 2001). Thus, robust root system can explore more soil volume and can uptake more $\mathrm{P}$ which is immobile by nature in soil (Arruda et al., 2016). Our results corroborated the findings of Alam et al. (2009) that higher availability of soil $\mathrm{P}$ had direct positive influence on effective tiller numbers. Talukdar et al., (2001) reported that rice seedlings dipped overnight in SSP amended soil-water slurry just before transplantation give grain yield $2.84 \mathrm{t} \mathrm{ha}^{-1}$, while basal recommended dose of SSP was $2.46 \mathrm{t} \mathrm{ha}^{-1}$ in an acidic alluvium soil of Brahmaputra valley. Balasubramanian et al. (1995) reported $13 \%$ higher grain yield of rice in SSP-rootdip method $\left(2.96 \mathrm{t} \mathrm{ha}^{-1}\right)$ over that $\left(2.61 \mathrm{t} \mathrm{ha}^{-1}\right)$ in SSP basal application as broadcast @ $26 \mathrm{~kg} \mathrm{P}_{2} \mathrm{O}_{5}$ ha $^{-1}$ from Madagascar. In this study, the SRD in SSP Soil slurry or SSP Soil slurry+PSB+RP showed maximum PRE and PUE compared to that in SSP broadcast and RP broadcast. Our findings clearly demonstrated the usefulness of SRD in SSP Soil slurry method with PSB+RP (half the recommended dose of RP i.e. $30 \mathrm{~kg}$ $\mathrm{ha}^{-1}$ ) in terms of early root growth, root vigour, higher $\mathrm{P}$ uptake in grain and straw, higher PUE and PRE. The actual $P$ concentration in plant tissue was increased by $\mathrm{P}$ uptake in plant, but may be diluted due to progressive plant growth if $\mathrm{P}$ supply couldn't be maintained by soil as per plant demand. This may lead to reduction in uptake of nutrient and nutrient stress condition may appear (Arruda et al., 2016). This might be the reason for relative lesser $\mathrm{P}$ content in plant tissue under SSP broadcast plot than that of SRD in SSP Soil slurry+PSB+RP plot. This result further indicated that SRD in SSP Soil slurry+PSB+RP method of $\mathrm{P}$ application could maintain a continuous supply 
for $\mathrm{P}$ to plants throughout the growing period. This was also evident from soil AvlP status at harvest that $\mathrm{PSB}+\mathrm{RP}$ plots and SRD in SSP Soil slurry+PSB+RP plots maintained significant higher level of soil available $\mathrm{P}$ pool at harvest in spite of maximum $\mathrm{P}$ uptake in grain and straw. This might be due to the addition of sparingly soluble RP along with PSB inoculation. Because RP is able to replenish the soil solution $\mathrm{P}_{\mathrm{i}}$ pool through PSB mediated slow dissolution of RP over the time and also contribution of organic $\mathrm{P}$ to solution $\mathrm{P}$ through higher PHA activity of PSB. These results were supported by the past finding that RP maintained higher amount of AvlP in soil than SSP (Mandal and Khan, 1972). Again, the combined application of RP and PSB further increased soil AvlP compared to their individual application (Thakuria et al., 2009; Borges Chagas et al., 2015). Thus, it seems that PSB+RP and SRD in SSP Soil slurry+PSB+RP application could maintain a synchrony between the supply of soil AvlP and the rate of $\mathrm{P}$ uptake in plant over the crop growing period. However, this phenomenon didn't hold true in SSP broadcast plots. Because, SSP broadcast plots failed to maintain higher level of soil AvlP pool at harvest. Though SSP broadcast plots supported higher P uptake in grains and straw, but PRE and PUE were much lower. The usefulness of SRD in SSP soil slurry+PSB+RP was also visible in fertile acid soil (clay loam Inceptisol having $\mathrm{pH}$ 5.56) under field experiment-II. The SSP soil slurry+PSB+RP plot able to support early root growth and $\mathrm{P}$ concentration in root and shoot at 45 DAT. Further, it was also evident that SSP soil slurry+PSB+RP plot was able to produce rice grain yield up to $5.8 \mathrm{tha}^{-1}$ which was significantly higher than $5.63 \mathrm{t} \mathrm{ha}^{-1}$ achieved under conventional method of $\mathrm{P}$ management $\left(\mathrm{N} / \mathrm{P}_{2} \mathrm{O}_{5} / \mathrm{K}_{2} \mathrm{O}\right.$ at 80:60:40 $\left.\mathrm{kg} \mathrm{ha}^{-1}\right)$. Overall, it was conclusive that the combined application of SRD in SSP Soil slurry+PSB+RP supported higher grain yield of rice compared to that in conventional method of P management under both infertile and fertile acid soils, and also maintained greater soil AvlP pool in spite of enhanced P uptake, PUE and PRE.

\section{Conclusions}

This investigation for the first time reported the optimum dose (112.5 mg kg-1 soil) of orthophosphate (in the form of SSP) and incubation duration (10 h) of SSP Soil slurry method for HYV rice tested in a strongly acid Inceptisol (sandy clay loam, pH 4.31). The SRD in SSP soil slurry could facilitate excess uptake of $\mathrm{P}$ in seedlings that has helped in better root growth and early establishment of rice crop in strongly to moderate acid soils (sandy clay loam $\mathrm{pH} 4.31$ to clay loam $\mathrm{pH}$ 5.56). The SRD in SSP Soil slurry when combined with $\mathrm{PSB}+\mathrm{RP}$ performed better in terms of more root volume, root and shoot $\mathrm{P}$ uptake at the early growth stage and higher grain yield, $50 \%$ reduction of $\mathrm{P}$ input quantity, higher $\mathrm{P}$ uptake in grain and straw, enhanced PUE and PRE in comparison to the existing conventional method of $\mathrm{P}$ management $\left(\mathrm{N} / \mathrm{P}_{2} \mathrm{O}_{5} / \mathrm{K}_{2} \mathrm{O}\right.$ at 80:60:40 $\mathrm{kg} \mathrm{ha}^{-1}$ ). Besides, the SRD in SSP Soil slurry+PSB+RP method could maintain a synchrony between the supply of soil AvlP and the rate of P uptake in rice crop over the crop growing period. So, we argue that this SSP Soil slurry+PSB+RP method may be exploited for managing $\mathrm{P}$ nutrition in transplanted rice grown in acid soils considering the comparable benefits in terms of yield and half the quantity of $P$ fertilizer input with that of existing conventional farmers' practice.

\section{Acknowledgements}

The first author [registration number CAU/61$\mathrm{A} / 11(\mathrm{PG})$ ] was supported by Central Agricultural University (Imphal), Manipur, India. The corresponding author acknowledged the Department of 
Biotechnology, Ministry of Science and Technology, Government of India for providing financial support to carry out this research [Grant no. BT/PR15208/ AGR/21/332/2011 dtd. 02-07-2012].

\section{References:}

Alam, M.M., Ali, M.H., Amin, A.K.M.R., Hasanuzzaman, M. 2009. Yield attributes, yield and harvest index of tree irrigated rice varieties under different levels of phosphorus. Adv. Biol. Res. 3, 132139.

Arruda, B., Rodrigues, M., Soltangheisi, A., Richardson, A.E., Andreote, F.D., Pavinato, P.S. 2016. Biological and morphological traits of sugarcane roots in relation to phosphorus uptake. J. Soil Sci. Plant Nutr. 16, 901-915.

Ashley, K., Cordell, D., Mavinic, D. 2011. A brief history of phosphorus: from the philosopher's stone to nutrient recovery and reuse. Chemosphere. 84 , 737-746.

Ayoub, A.T. 1999. Fertilizers and the environment. Nutr. Cycl. Agroecosys. 55, 17-121.

Balasubramanian, V., Rabeson, R., Razafinjara, L., Ratsimandresy, J. 1995. Rice soil constraints and fertility management in the highlands of Madagascar: Fragile lives in fragile ecosystems. Proceeding of the International Rice Research Conference, IRRI, Manila, Philippines, pp: 976.

Bhattacharyya, P., Nayak, A.K., Shahid, M., Tripathi, R., Mohanty, S., Kumar, A., Raja, R., Panda, B.B., Lal, B., Gautam, P., Swain, C.K. 2015. Effects of 42-year long-term fertilizer management on soil phosphorus availability, fractionation, adsorptiondesorption isotherm and plant uptake in flooded tropical rice. Crop. J. 3.5, 387-395.

Bieleski, R.L., Ferguson, I.B. 1983. Physiology and metabolism of phosphate and its compounds. In:
Inorganic plant nutrition. Springer Berlin Heidelberg, Berlin. pp: 422-449.

Bijay-Singh, Singh V.K. 2017. Fertilizer management in rice. In: B.S. Chauhan et al. (eds.), Rice Production Worldwide, Springer International Publishing AG. pp: 217-253. DOI 10.1007/9783-319-47516-5_10

Borges Chagas, L.F., Chagas Junior, A.F., Rodrigues de Carvalho, M., de Oliveira Miller, L., Colonia, O. 2015. Evaluation of the phosphate solubilization potential of Trichoderma strains (Trichoplus JCO) and effects on rice biomass. J. Soil Sci Plant Nutr. 15, 794-804.

Bouyoucos, G.J., 1927. The hydrometer as a new method for the mechanical analysis of soil. Soil Sic. 23, 343-354.

Brookes, P.C., Joergensen, R.G. 2006. Microbial biomass measurement by fumigation-extraction. In: Bloem, J., Hopkins, D.W., Benedetti, A. (ed). Microbiological methods for assessing soil quality. CABI Publishing, UK, pp: 77-83.

Cate, R.B., Nelson, L.A. 1971. A simple statistical procedure for partitioning soil test correlation data into two classes. Soil Sci. Soc. Am. Proc. 35, 658-659.

Chatterjee, A.K., Khan, S.K. 2005. Evaluation of phosphate rocks compacted with different soluble phosphate and sulphur in rice (Oryza sativa)wheat (Triticum aestivum) and rice-rapeseed (Brrassica compenstris var yellow sarson) crop sequences in Alfisol. Indian J. Agric. Sci. 758, 493-5.

Cordell, D., Drangert, J.O., White. S. 2009. The story of phosphorus: global food security and food for thought. Global Environ. Chang. 19, 292-305.

Day, P.R. 1965. Particle fractionation and particle-size analysis. In: Black, C.A. (ed). Methods of soil analysis. Am. Soc. Agron. Madison, pp: 545-567. 
Fageria, N.K., Heinemann, A.B., Reis, R.A. 2014. Comparative Efficiency of Phosphorus Source for Upland Rice Production. Commun. Soil Sci. Plant Anal. 45.10, 1399-1420.

Fageria, N.K., Santos, A.B., Carvalho, M.C.S. 2015. Agronomic Evaluation of Phosphorus Sources Applied to Upland and Lowland Rice. Commun. Soil Sci. Plant Anal. 46.9, 1097-1111.

FAOSTAT. 2016. http://faostat3.fao.org/download/Q/ QC/E. Accessed 13 Feb 2016

Faucon, M.P., Houben, D., Reynoird, J.P., MercadalDulaurent, A.M., Armand, R., Lambers, H. 2015. Advances and perspectives to improve the phosphorus availability in cropping systems for agroecological phosphorus management. Adv. Agron. 134, 51-79.

Gilbert, N. 2009. The disappearing nutrient. Nat. 461, 716-718.

Harrington, J.T., Mexal, J.G., Fisher, J.T. 1994. Volume displacement provides a quick and accurate way to quantify new root production. Tree Plant Notes. 45, 121-124.

Hooper, J.R. 1991. Progress of research in Madagascar: Toward identifying 75 low input technological improvements by 1995. Paper presented at the Rice Research Seminar, 4 Apr. 1991. IRRI, Manila, Philippines.

Lee, R.B., Ratcliffe, R.G., Southon, T.E. 1990. 31 $P$ NMR measurements of the cytoplasmic and vacuolar Pi content of mature maize roots: relationships with phosphorus status and phosphate fluxes. J. Exp. Bot. 41, 1063-1078.

Lu, R., Bai-fan, J., Ching-kwei, L. 1982. Phosphorus management for submerged rice soils. Institute of Soil Science, Academia Sinica, Nanjing, China. pp:11.
Mandal, L.N., Khan, S.K. 1972. Release of phosphorus from insoluble phosphatic materials in acidic lowland rice soils. J. Indian Soc. Soil Sci. 20, 19-25.

Manoj-Kumar, Swarup, A., Patra, A.K., Chandrakala, J.U., Manjaiah, K.M, 2012. Effect of elevated $\mathrm{CO}_{2}$ and temperature on phosphorus efficiency of wheat grown in an Inceptisol of subtropical India. Plant Soil Environ. 58, 230-235.

Martínez, O.A., Crowley, D.E., Mora, M.L., Jorquera, M.A. 2015. Short-term study shows that phytatemineralizing rhizobacteria inoculation affects the biomass, phosphorus (P) uptake and rhizosphere properties of cereal plants. J. Soil Sci. Plant Nutr. 15, 153-166.

Navarro, J.M., Botella, M.A., Cerdá, A., Martinez, V. 2001. Phosphorus uptake and translocation in salt-stressed melon plants. J. Plant Physiol. 158, 375-381.

Page, A.L., Miller, R.H., Keeney, D.R. 1982. Methods of Soil Analysis, Part II- Chemical and Microbiological Properties, Second Edition, Agronomy Monograph No.9, American Society of Agronomy, Inc., Soil Science Society of America, Inc., Madison, Wisconsin, USA. pp.1159.

Ramaekers, L., Remans, R., Rao, I.M., Blair, M.W., Vanderleyden, J. 2010. Strategies for improving phosphorus acquisition efficiency of crop plants. Field Crops Res. 117, 169-176.

Redel, Y., Cartes, P., Demanet, R., Velásquez, G., Poblete-Grant, P., Bol, R., Mora, M.L. 2016. Assessment of phosphorus status influenced by $\mathrm{Al}$ and Fe compounds in volcanic grassland soils. J. Soil Sci. Plant Nutr. 16, 490-506.

Richardson, A.E., Hocking, P.J., Simpson, R.J., George, T.S. 2009. Plant mechanisms to optimise access to soil phosphorus. Crop Pasture Sci. 60, 124-143. 
Ru-kun, L., Bai-fan, J., Ching-Kwei, L. 1982. Phosphorus management for submerged rice soils. Institute of Soil Science, Academia Sinica, Nanjing, China. pp: 11.

Tabatabai, M.A., Bremner, J.M. 1969. Use of p-nitrophenyl phosphate for assay of soil phosphatase activity. Soil Biol. Biochem. 1, 301-307.

Talukdar, N.C., Thakuria, D., Bordoloi, L., Goswami, C. 2001. Half a decade research on utilization of soil biological agents as components of nutrient management for quality and resilience of agro and forest ecosystem. In: Three Decades of Research in Biofertilizers and Organic Farming in Northeast India. Ed. Yadav A.K., Roychoudhury S. Jointly published by Assam Agricultural University, Jorhat, Assam and Regional Biofertilizer Development Centre, Imphal, Manipur. pp: 7-33.
Thakuria, D., Talukdar, N.C., Goswami, C., Hazarika, S., Kalita, M.C., Bending, G.D. 2009. Evaluation of rice-legume-rice cropping system on grain yield, nutrient uptake, nitrogen fixation, and chemical, physical, and biological properties of soil. Biol. Fertil. Soils. 45, 237-251.

von Uexküll, H.R., Mutert, E. 1995. Global extent, development and economic impact of acid soils. Plant Soil. 171, 1-15.

Wardle, D.A., Walker, L.R., Bardgett, R.D. 2004. Ecosystem properties and forest decline in contrasting long-term chronosequences. Sci. 305, 509-513. 